DOI 10.15290/cnisk.2020.02.09.05

ŁUKASZ JĘDRZEJSKI

http://orcid.org/0000-0002-2632-9117

Uniwersytet Marii Curie-Skłodowskiej w Lublinie

\title{
Dyskurs polityczny w Polskiej Rzeczypospolitej Ludowej na łamach tygodnika „Zwierciadło”. Przypadek sporu o Tysiąclecie Państwa Polskiego ${ }^{1}$
}

\section{Streszczenie}

Celem artykułu jest zaprezentowanie formułowanego przez władze partyjne Polskiej Rzeczypospolitej Ludowej dyskursu politycznego w okresie sporu o Tysiąclecie Państwa Polskiego na łamach ważnego ówcześnie tytułu prasowego, jakim było „Zwierciadło”. Pytania badawcze sformułowane w tekście odnosiły się do następujących kwestii: (1) Jakie specyficzne cechy posiadał profil prasowy periodyku? (2) Jakie specyficzne idiolekty językowe i słowa sztandarowe występowały w przekazie prasowym w trakcie uroczystości Tysiąclecia? (3) Jakie formy gatunkowe dominowały w formułowanym przekazie prasowym?

Słowa kluczowe: Polska Rzeczpospolita Ludowa, Polska Zjednoczona Partia Robotnicza, „Zwierciadło”, Władysław Gomułka, Stefan Wyszyński

1 Publikacja przygotowana/finansowana w ramach programu Ministra Nauki i Szkolnictwa Wyższego pod nazwa DIALOG w latach 2019-2021. Jest wynikiem udziału w projekcie badawczym pt. „Ośrodek badań historii kobiet”, nr 0016/DLG/2019/10. 


\title{
POLITICAL DISCOURSE IN THE POLISH PEOPLE'S REPUBLIC IN THE WEEKLY ZWIERCIADEO. A CASE OF DISPUTE OVER THE MILLENNIUM OF THE POLISH STATE
}

\begin{abstract}
The purpose of the article is to present the political discourse formulated by the party authorities of the Polish People's Republic during the Dispute over the Millennium of the Polish State in the then-important press title which was Zwierciadto [The Mirror]. Research questions formulated in the text referred to the following issues: 1) What specific features did the periodical have? 2) What specific language idiolects and banner words were present in the press during the Millennium Celebration? 3) What genres dominated the formulated press release?
\end{abstract}

Keywords: Polish People's Republic, Polish United Workers' Party, Zwierciadło, Władysław Gomułka, Stefan Wyszyński

\section{Uwagi wstępne}

Zręby systemu prasowego w Polsce drugiej połowy XX w. zaczęły kształtować się od 1944 r. jako efekt sformowania się na terenach Polski lubelskiej, czyli państwa $z$ okresu funkcjonowania Polskiego Komitetu Wyzwolenia Narodowego w Lublinie i Tymczasowego Rządu Jedności Narodowej w Warszawie. Po zakończeniu II wojny światowej Polska znalazła się w sowieckiej strefie wpływów ukształtowanej w Europie Środkowo-Wschodniej. To ze stolicy państwa sowieckiego zaczęły płynąć do Polski dyrektywy odnoszace się między innymi do budowy podstaw przyszłego, wzorowanego na modelu sowieckim systemu medialnego obowiązujacego w Polsce. W latach 1944-1945 tworzenie się nowego ładu medialnego warunkował między innymi następujący czynnik polityczny. Były to plany Polskiej Partii Robotniczej - dominujacej siły partyjnej w systemie politycznym Polski w latach 40. Celem partii przejmującej władzę w kraju była budowa komunistycznej doktryny prasowej nazywanej leninowska koncepcja prasy ${ }^{2}$.

Leninowska koncepcja prasy zakładała pełną podległość środków masowego przekazu władzy państwowej, którą do roku 1948 stanowiło

2 Katarzyna Pokorna-Ignatowicz, Robotnicza Spótdzielnia Wydawnicza „Prasa-Ksiażka-Ruch” w polskim systemie medialnym, (Warszawa : Oficyna Wydawnicza AFM, 2016), 14. 
kierownictwo PPR, a od 1948 r. Polskiej Zjednoczonej Partii Robotniczej. Według założeń koncepcji media stały się narzędziem PZPR sprawującej władzę państwową w Polsce. Partia wykorzystywała środki masowego przekazu do ideologicznego oddziaływania na społeczeństwo. W działaniach politycznych wykazywano dążność do kształtowania przez media poglądów, postaw i zachowań ludzkich. System medialny w PRL charakteryzował się cechami przynależnymi wszystkim niedemokratycznym systemom medialnym. Do konstytutywnych cech systemu należało zaliczyć między innymi:

(1) kontrolę władz państwowych nad rynkiem mediów, (2) koncesjonowanie działalności wydawniczej, (3) cenzurę prewencyjna, czyli wstępna kontrolę treści zamieszczanych w poszczególnych tytułach prasowych nadzorowana głównie przez redaktorów naczelnych pism, (4) profesjonalne działania cenzorskie prowadzone przez powołana do tego specjalna państwową instytucję, jakim był Główny Urząd Kontroli Prasy Publikacji i Widowisk. Ponadto prasa w systemie politycznym PRL należała do uspołecznionych wydawców. Na rynku prasowym nie działały mechanizmy rynkowe, ponieważ sektor prasowy podobnie jak cała gospodarka państwa był centralnie planowany (sterowany) $)^{3}$.

Celem niniejszego artykułu jest przedstawienie formułowanego przez władze państwowe dyskursu politycznego prezentowanego przez Komitet Centralny PZPR i episkopat Polski w trakcie przebiegu wydarzeń o charakterze politycznym i religijnym przypadajacych na lata 19601966, nazywanych w literaturze przedmiotu sporem o Tysiąclecie Państwa Polskiego. Spór toczył się na łamach ważnego kanału treści społecznych i politycznych, jakim było czasopismo pod tytułem „Zwierciadło”. Problematyka dotycząca funkcjonowania prasy dla kobiet we współczesnie prowadzonych badaniach prasoznawczych jest dość dobrze spenetrowana. Tę problematykę podejmowali liczni badacze: historycy, politolodzy, socjolodzy, medioznawcy ${ }^{4}$. Istotnym dorobkiem w tym zakresie

3 Katarzyna Pokorna-Ignatowicz, „Od leninowskiej koncepcji prasy do wolnych mediów. Koncepcja "nowego ładu informacyjnego" w "Porozumieniach Okragłego Stołu", w: eadem (red.), Polski system medialny 1989-2011, (Kraków : Oficyna Wydawnicza AFM, 2013), 13.

4 Vide: Zbigniew Bajka, Czytelnictwo prasy w Polsce w 1986 roku, (Kraków : RSW-Prasa-Ksiażka-Ruch, 1987), passim; Ryszard Kalbarczyk, „Kto czyta pismo kobiece?”, Nasze problemy, t. 3, 1979, 35-40; Anna Maliszewska, „Wzory wychowawcze w prasie kobiecej (szkoła i rodzina jako instytucje wychowawcze)", Zeszyty Prasoznawcze, t. 4, 1975, 
może poszczycić się Zofia Sokó15. Badania poświęcone funkcjonowaniu prasy dla kobiet $\mathrm{w}$ systemie politycznym PRL $z$ powodzeniem realizuja badaczki skupione w ośrodku w Białymstoku ${ }^{6}$. Dobrym forum wymiany informacji naukowych i wyników prowadzonych badań są cyklicznie realizowane w ośrodku białostockim spotkania w ramach Ośrodka Badań Historii Kobiet, centrum badań historii kobiet polskich zainicjowanym przez Prezes Instytutu Studiów Kobiecych Małgorzatę Dajnowicz ${ }^{7}$.

Cezura czasowa przyjęta do prezentacji dyskursu politycznego w okresie sporu o Tysiaclecie obejmowała lata 1957-1966 i determinowana były oficjalnym rozpoczęciem przygotowań do obchodów Wielkiej Nowenny przygotowywanej przez Kościół katolicki na czele z prymasem Polski kardynałem Stefanem Wyszyńskim w 1957 r. Z kolei władze państwowe na czele $z$ I sekretarzem PZPR Władysławem Gomułką rozpoczęły przygotowania konkurencyjnych obchodów Tysiąclecia Państwa Polskiego w roku 1958. Rozpoczęcie państwowych przygotowań obchodów tysiąclecia sankcjonowane było przez dwa urzędowe dokumenty: Uchwate Rady Państwa $z$ dnia 18 II 1958 r. w sprawie przygotowan Obchodów Tysiąclecia Państwa Polskiego ${ }^{8}$ oraz Uchwałę Sejmu Polskiej

15-25; Franciszek Adamski, Modele małżeństwa i rodziny a kultura masowa, (Warszawa : PWN, 1970), passim; idem, „Konflikty małżeńskie i ich źródła na łamach Kobiety i Życia”, Zeszyty Prasoznawcze, t. 1, 1978, passim; Krystyna Konarska, Maria Łoś, Małgorzata Łaskot, „Czasopisma kobiece czy rodzinne?”, Więź, t. 9, 1965, passim; Sabina Szczepańska, „Kobieta - zwierzę polityczne?”, w: Małgorzata Radkiewicz (red.), Gender - kultura - społeczeństwo, (Kraków : Wydawnictwo Rabit, 2002), 91-100.

5 Vide: Zofia Sokół, „Transformacja czasopism kobiecych w Polsce (1989-1997)”, Rocznik Historii Prasy Polskiej, t. 1, 1998, 191-217; eadem, „Wzór osobowy kobiety i model rodziny propagowany na łamach prasy kobiecej w latach 1945-1990", w: Weronika Chańska, Danuta Ulicka (red.), Polskie oblicza feminizmu, (Warszawa : Wydawnictwo Uniwersytetu Warszawskiego, 2000), 66-86.

6 Vide: Urszula Ćwik, „Zagadnienia praw kobiet na łamach Kobiety i Życia (1970-1989)”, Czasopismo Naukowe Instytutu Studiów Kobiecych, t. 1, 2016, 66-83; Agnieszka Drozdowska, „Liga Kobiet w województwie białostockim - stan badań i postulaty badawcze”, Czasopismo Naukowe Instytutu Studiów Kobiecych, t. 2(5), 2018, 112-127; Justyna Zajko-Czochańska, „Kobiety i wybory na łamach Przyjaciólki w latach 1956-1976”, Czasopismo Naukowe Instytutu Studiów Kobiecych, nr 1(6), 2019, 138-150.

7 W ramach projektu Ośrodka Historii Kobiet prowadzone są badania porównawcze nad dziejami kobiet w różnych epokach historycznych, działalnościa kobiet w zaborze pruskim, działalnościa polskich dziennikarek w środowiskach emigracyjnych, kobiecymi ego dokumentami, prasa dla kobiet w II RP i po 1945 r., organizacjami kobiecymi w PRL. Stowarzyszenie Instytut Studiów Kobiecych [dostęp: 3.01.2020]. Dostępne w World Wide Web: http://www.isk.bialystok.pl/.

8 Uchwała Rady Państwa z dnia 18 II 1958 r. w sprawie przygotowań do Obchodów Tysiaclecia Państwa Polskiego, „Monitor Polski 1958, nr 12, poz. 78, 1. 
Rzeczypospolitej Ludowej z dnia 25 II 1958 r. w sprawie Obchodów Tysiaclecia Państwa Polskiego 9 . Cezura końcowa przyjęta do przeprowadzenia badania obejmowała datę 22 lipca 1966 r. Na ten dzień władze państwowe przygotowały defiladę historyczno-wojskową. Uroczystości z okazji ustanowienia Manifestu PKWN stanowiły końcową datę państwowych uroczystości związanych $z$ Tysiącleciem państwa ${ }^{10}$.

Uwagę badawczą warto było skupić na następujących kwestiach: (1) Jakie specyficzne cechy posiadał profil prasowy periodyku? (2) Jakie specyficzne idiolekty językowe i słowa sztandarowe występowały w przekazie prasowym w trakcie uroczystości Tysiąclecia? (3) Jakie formy gatunkowe dominowały w formułowanym przekazie prasowym? Przedstawione pytania badawcze determinowały kształt tekstu. Artykuł posiadał strukturę problemowa $z$ zachowaniem przyjętych ram temporalnych. Składał się ze wstępu i części poświęconej rozważaniom merytorycznym. Zakończenie dopełniały sformułowane wnioski.

Dobór i obsługa narzędzi pomiarowych, użytecznych dla sporzadzenia artykułu, były zdeterminowane charakterem politologii i jej badań zjawisk i procesów politycznych. Przedmiotem eksploracji były komunikaty polityczne rozumiane jako specyficzne ogłoszenia zawierające informacje lub kształtujace postawy i dające możliwość: (1) wykorzystania zasobów ludzkich in gremio bądź indywidualnych jednostek ludzkich, (2) wprowadzenia rozwiąań systemowych w sferze polityki, (3) wykonywania czy delegowania obowiązów, (4) wpływania na instytucje i ludzi angażujących się w życie polityczne. Ujęcie idiograficzne pozwalało na ukazanie uszczegółowionego obrazu świata politycznego. Wprawdzie zawierało sfragmentaryzowaną wiedzę pokazująca głównie przebieg konfliktu między państwem a Kościołem katolickim z perspektywy władz państwowych, ale miało funkcjonalny charakter, umożliwiający powiąanie efektów opisu obserwacji z wartościowaniem zjawisk i procesów politycznych ${ }^{11}$.

\footnotetext{
9 Uchwała Sejmu Polskiej Rzeczypospolitej Ludowej z dnia 25 II 1958 r. w prawie obchodów Tysiaclecia Państwa Polskiego, „Monitor Polski” 1958, nr 16, poz. 58.

${ }_{10} \mathrm{~W}$ związk $\mathrm{z}$ tym, że w artykule przedstawiono formowanie się dyskursu na łamach „Zwierciadła” będącego jednym $z$ państwowych tytułów prasowych, dla ujednolicenia nazewnictwa uroczystości zdecydowano się na używanie nazwy Tysiąclecie. Wybór determinowany był dominacją treści zwiąanych $z$ państwowymi obchodami uroczystości na łamach „Zwierciadła”.

11 Zbigniew Kantyka, „Politologia (I)”, w: Wojciech Sokół, Marek Żmigrodzki (red.), Encyklopedia politologii, t. 1, Pojeccia, teorie i metody, (Warszawa : Wydawnictwo Wolters Kluwer, 2016), 481.
} 
Przed rozpoczęciem badań skonstruowana została lista kodów tematycznych, użyteczna przy późniejszym ustalaniu swego rodzaju paralelnego zestawienia zagadnień, $z$ których tworzył się szkielet tekstu. Selekcjonując odpowiednie słowa klucze ${ }^{12}$, częściowo oparto się na istniejących już zestawach kategorii politologicznych i historycznych, znanych $z$ literatury przedmiotu, co dawało podstawę do ustalenia wiedzy o preferencjach twórców dyskursu politycznego w prezentowanym okresie istnienia PRL. Na liście znalazły się główne kody, takie jak: ideologia, życie polityczne, Szkoły Tysiąclecia, obchody 550. rocznicy bitwy pod Grunwaldem, Sztafety Tysiąclecia, list biskupów polskich do biskupów niemieckich, Polska jako przedmurze chrześcijaństwa. Takie postępowanie było niezbędne podczas wstępnej analizy zebranego materiału na etapie eksplorowania źródeł, a następnie interpretowania zebranej dokumentacji. Okazało się też korzystne dla finalnego redagowania tekstu, szczególnie podczas sprawdzania stopnia logiczności i przejrzystości treści artykułu.

Podczas przygotowywania artykułu użyteczna była metoda analizy systemowej. Dzięki niej periodyk „Zwierciadło” rozpatrywano jako instytucję polityczną stanowiąca element systemu propagandowego PRL. W artykule zastosowano technikę analizy zawartości mediów. Analiza dotyczyła propagandowej zawartości komunikatów politycznych formułowanych przez partyjnych decydentów i zespół redakcyjny „Zwierciadła”. Szczególna uwaga zwrócona była na frekwencyjność zawartych w komunikatach słów sztandarowych stanowiacych elementy specyficznego metajęzyka używanego przez twórców komunikowania politycznego periodyku. Słowa sztandarowe odnosiły się zazwyczaj do określenia panującej w państwie ideologii mającej wszechogarniający charakter i obowiazującego w latach 60. XX w. w Polsce sposobu formułowania dyskursu politycznego. Stanowiły również nośne hasła propagandowe formułowane przez partyjnych decydentów, a odnoszące się do życia politycznego, społecznego. Technika była spożytkowana, aby scharakteryzować specyficzne idiolekty językowe zawarte w przekazie komunikacyjnym

12 Formułowane przez polityków słowa klucze uobecnione na łamach prasy przybierały nierzadko formę skrzydlatych słów, czyli takich, które są często przytaczane i rozpowszechniane, a ich autorstwo jest na ogół znane. Pod względem formalnym pod pojęciem skrzydlatych słów występuja najczęściej związki wyrazowe, a więc słowa o charakterze nominalnym, Henryk Markiewicz, Andrzej Romanowski, Skrzydlate słowa, (Warszawa : Państowy Instytut Wydawniczy, 1990), 6-7. 
do opisu propagandowego obrazu rzeczywistości politycznej i społecznej ze szczególnym uwzględnieniem sposobu prowadzenia sporu politycznego między episkopatem a Komitetem Centralnym PZPR. Kryterium klasyfikacyjnym analizy były przekazy słowne formułowane $\mathrm{w}$ komunikatach redakcyjnych. Medialna analiza treści zawartych w „Zwierciadle" realizowana była na podstawie słownych wypowiedzi dziennikarzy, działaczek społecznych i partyjnych decydentów, utrwalonych w zapisie prasowym $^{13}$.

Przy sporządzaniu artykułu wykorzystano głównie materiały źródłowe, stanowiace artykuły prasowe zamieszczane na łamach periodyku. Dla dopełnienia wywodu spożytkowano szereg opracowań naukowych $\mathrm{z}$ zakresu historii, nauk o polityce, nauk o komunikacji społecznej i mediach.

\section{Profil prasowy}

W działalności periodyku można było wyszczególnić trzy okresy wydawnicze przypadające na następujące przedziały czasowe. Okres pierwszy od roku 1957 do 1961, gdy „Zwierciadło: tygodnik ilustrowany” związane było $z$ działalnością Ligi Kobiet ${ }^{14}$. Okres drugi przypadał na lata 1961-1981. W tym czasie tygodnik wydawany był przez Robotnicza Spółdzielnię Wydawnicza „Prasa-Książka-Ruch”. Okres trzeci rozpoczął się w roku 1982 i trwał do roku 1990. Okres ostatni to czas transformacji systemowej, gdy od 1991 r. po przemianach ustrojowych następowała zmiana stosunków własnościowych ${ }^{15}$.

13 Walery Pisarek, Wstę do nauki o komunikowaniu, (Warszawa : Wydawnictwa Akademickie i Profesjonalne, 2008), 245-249; idem, O mediach i języku, (Kraków : Wydawnictwo Universitas, 2007), 47-63; Małgorzata Lisowska-Magdziarz, Analiza tekstu $w$ dyskursie medialnym, (Kraków : Wydawnictwo Uniwersytetu Jagiellońskiego, 2006), passim.

14 Zofia Sokól, Prasa kobieca $w$ Polsce $w$ latach 1945-1995, (Rzeszów : Wydawnictwo Wyższej Szkoły Pedagogicznej, 1998), 146-147.

15 Jak wskazuje Małgorzata Dajnowicz: „Społeczno-Obywatelska Liga Kobiet powstała w sierpniu 1945 roku ... Zarząd Główny ... Tworzyły ... komunistki z Polskiej Partii Robotniczej socjalistki z Polskiej Partii Socjalistycznej. Jedna reprezentująca Polskie Stronnictwo Ludowe, jedna ze Stronnictwa Demokratycznego oraz jedna bezpartyjna ... Organizacja funkcjonująca na samym początku bez wyraźnych wytycznych, programu i statutu $z$ jednej strony miała być wielonurtowa ..., monopartyjna i masowo dostosowana. Dostosowana do potrzeb nowej rzeczywistości Ludowej Polski powojennej ... Celem Ligi miało być także "Wychowanie kobiety, obywatelki, świadomej swoich praw i obowiazków w stosunku do Ojczyzny i społeczeństwa"”, Małgorzata Dajnowicz, "Walka o pokój" w wypowiedziach propagandowych publikowanych na łamach "Naszej Pracy" - biuletynie 
Powołania nowego pisma adresowanego do środowisk kobiecych miały domagać się kobiece środowiska inteligenckie. Jak wskazuje Małgorzata Dajnowicz: „Nowe pismo miało być adresowane do kobiet o wyższych niż przeciętne ambicjach intelektualnych, szerokich zainteresowaniach, poszukujacych możliwości konfrontacji własnych przemyśleń, opinii, poglądów z tym co może, powinno zaoferować... "Zwierciadło""16.

Pierwszy numer czasopisma ukazał się 19 maja 1957 r. Funkcję redaktor naczelnej periodyku pełniła Alina Rebane. $Z$ redakcja magazynu pracę podjęło grono uznanych publicystów nierzadko legitymujących się już sporym doświadczeniem prasowym. Można było zaliczyć do nich między innymi: Mariana Bieleckiego, Zofię Bystrzycką, Krystynę Dobrowolska, Janinę Janicką, Romana Jurysia, Eryka Lipińskiego, Czesławę Szymańską ${ }^{17}$. Okładka „Zwierciadła” drukowana była zawsze w technice technikoloru. Motywami dominującymi były zdjęcia kobiet, nierzadko ikon ówczesnej kultury popularnej, takich jak: Hanka Bielicka, Danuta Szaflarska, Barbara Krafftówna. Autorem zdjęć kobiet umieszczanych na stronie tytułowej często był uznany fotograf Edward Hartwig. Znakiem identyfikującym czasopismo była charakterystyczna winieta prasowa ukazująca tytuł tygodnika w lustrzanym odbiciu. W wewnętrznej szacie graficznej dominował kolor czarno-biały, choć dla wyróżnienia fragmentów tekstów stosowano kolorowe tła (żółte, zielone, czerwone, różowe, fioletowe). Periodyk liczył zazwyczaj około 16 stronic, aczkolwiek były i dłuższe wydania numerów specjalnych. Na łamach tygodnika w formie recenzji kinowych, teatralnych pojawiały się artykuły odnoszące się do spraw teatru i filmu. Publikowane były recenzje nowości ksiażkowych, powieści dedykowanych kobietom. Jedną z głównych stałych rubryk była Serce w rozterce. Stawała się ona platformą wymiany doświadczeń sercowych, miłosnych między czytelniczkami tygodnika a redakcja. Wymiany doświadczeń przybierały formę listowną popularną w ówczesnym czasie na łamach pism dla kobiet. Kolejną ze stałych rubryk „Zwierciadła” była

Ligi Kobiet (1947-1953)", w: Ewa Maj, Wojciech Sokół, Anna Szwed-Walczak, Łukasz Jędrzejski (red.), Bezpieczeństwo Europy - bezpieczeństwo Polski, t. 5, (Lublin : Wydawnictwo Uniwersytetu Marii Curie-Skłodowskiej, 2017), 411-413, Vide: Anna Marcinkiewicz-Kaczmarczyk, „Rola kobiety w Polsce Ludowej w świetle treści propagandowych rozpowszechnianych przez Ligę Kobiet w latach 1946-1956", Dzieje Najnowsze, R. L, z. 2, 2018, 150-151.

16 Małgorzata Dajnowicz, "ZWwierciadło" - platforma polityczna Ligi Kobiet w okresie PRL (1957-1961, 1982-1989)", Rocznik Historii Prasy Polskiej, t. 20, 2017, 73-74.

17 Ibidem, 75. 
ta pod tytułem Twarze „Zwierciadła”. Prezentowano w niej sylwetki znanych ludzi ze sfery polityki, kultury, dla uatrakcyjnienia przekazu treści w opisywanej rubryce umieszczano zdjęcia osób, którym były poświęcone zamieszczane materiały. Na łamach tygodnika w latach 60 . były publikowane również reportaże pokazujące sylwetki wybranych przez redakcje twórców kultury ludowej. Najczęściej prezentowano działalność twórców ludowych (rzeźbiarzy) tworzacych ludowe świątki w swych przydomowych zagrodach ${ }^{18}$. Treści o charakterze politycznym zamieszczane były zawsze na stronie drugiej tygodnika.

Mimo że w założeniach „Zwierciadło” miało być platforma prasowa upowszechniająca działalność Ligi Kobiet, problematyka ligowa od poczatku zajmowała mało miejsca w agendzie medialnej tygodnika. Sprawy związane $z$ działalnościa Ligi poruszane były na łamach „Zwierciadła” głównie przez Alicję Musiałową, do 1965 r. przewodniczącą Zarządu Głównego Ligi Kobiet. Intensyfikacja treści związanych z działalnościa Ligi pojawiała się zazwyczaj przy okazji obchodów Międzynarodowego Dnia Kobiet, wyborów do Rad Narodowych, Sejmu, Zjazdów PZPR.

Rekapitulując treści związane $z$ nakreśleniem profilu prasowego periodyku, należało zaznaczyć, że: tygodnik w założeniach twórców miał pełnić rolę sojusznika Ligi Kobiet w rozwiazywaniu problemów o charakterze społecznym i politycznym. W założeniach redakcyjnych na łamach pisma miała być prezentowana problematyka zbieżna $z$ zainteresowaniami czytelniczek, jednak poprzez ukazanie działalności Ligi Kobiet i prezentację agendy politycznej dażono do popularyzowania założeń ładu polityczno-społecznego zbieżnego $z$ podstawowymi kategoriami myśli politycznej PZPR ${ }^{19}$.

\section{Spór o Tysiąclecie}

Geneza przygotowań do obchodów Tysiąclecia sięga 1946 r. Pomysłodawca uczczenia obchodów Tysiąclecia był Witold Hensel, archeolog związany ze środowiskiem Instytutu Zachodniego w Poznaniu. Postulował podjęcie na szeroka skalę badań archeologicznych na terenach

18 Vide: LM, ŻM, Ojciec $i$ syn, „Zwierciadło”, t. 46, 1966, 8.

19 Małgorzata Dajnowicz, „Posłanki Ligi Kobiet Polskich i wybory parlamentarne 1989 roku (prezentacja w świetle "Zwierciadła»", w: Małgorzata Dajnowicz, Adam Miodowski (red.), Polityka i politycy w prasie XX $i$ XXI wieku. Polityka w prasie kobiecej, (Białystok: Wydawnictwo Uniwersytetu w Białymstoku, 2019), 206. 
dawnych grodów stołecznych, Gniezna i Poznania. Badania miały uzasadnić tezę o autochtonizmie Słowian, czyli pradawnym zasiedleniu przez ludy słowiańskie ziem rozciagających się między Odrą, Bugiem, Bałtykiem i Karpatami. Rozszerzeniem przez historyków idei autochtonizmu Słowian była idea Polski Piastowskiej, uzasadniajacca powrót do „macierzy” Ziem Zachodnich i Północnych jako pradawnych terenów Polski z okresu panowania księcia Mieszka I i Bolesławów. W oficjalnej interpretacji państwowej był to wynik sprawiedliwości dziejowej i sposób argumentacji potwierdzający polskie prawo do tak zwanych Ziem Odzyskanych $^{20}$.

Z inicjatywą uczczenia Tysiąclecia Chrztu Polski wystapiły również środowiska kościelne. Jako pierwszy inicjatywę powzią ówczesny prymas Polski kardynał August Hlond. Wzywał teologów i historyków Kościoła do przygotowania prac naukowych obrazujących wszechstronna działalność instytucji kościelnych na przestrzeni tysiąca lat państwowości polskiej. Od roku 1947 po wydaniu przez episkopat listu wzywającego wiernych do bojkotu prasy antyreligijnej wyrażono protest przeciwko ateistycznej indoktrynacji młodzieży. Doszło wtedy do pogorszenia stosunków między PPR a Kościołem. Nakreślony stan trwał praktycznie do roku 1956, gdy po przemianach październikowych na czele partii staną Władysław Gomułka i doprowadził do istotnej modyfikacji polityki wyznaniowej PRL. Wymiernym efektem zapoczatkowanych przez nowe władze państwowe zmian była decyzja o powrocie do Warszawy z Komańczy ówczesnego prymasa kardynała Stefana Wyszyńskiego ${ }^{21}$.

Jak wspomniano we wstępnej części artykułu, asumptem do rozpoczęcia obchodów Tysiąclecia przez władze państwowe była Uchwała Rady Państwa z dnia 18 II 1958 r. w sprawie przygotowań Obchodów Tysiaclecia Państwa Polskiego. W ocenie Aleksandra Zawadzkiego Przewodniczącego Rady Państwa obchody:

Miały ... stać się uroczystościami ogólnonarodowymi, obejmującymi swoim zasięgiem cały kraj i Polonię, a także zmobilizować Polaków do

\footnotetext{
20 Anita Młynarczyk-Tomczyk, Obchody „polskiego Tysiaclecia” (1957-1966/67), (Kielce : Wydawnictwo Uniwersytetu Jana Kochanowskiego, 2019), 41-43.

${ }^{21}$ Vide: Bartłomiej Noszczak, Polityka wobec Kościoła rzymskokatolickiego w Polsce $w$ okresie internowania prymasa Stefana Wyszyńskiego 1953-1956, (Warszawa : Wydawnictwo Instytutu Pamięci Narodowej, 2008), passim; Marek Truszczykowski, Kościót Rzymskokatolicki $w$ Polsce na tle polityki władz partyjno-państwowych PRL $w$ latach 1956-1980, (Szulborze Wielkie : BW, 2011), 13-70.
} 
„wytężonej pracy i nieustannego wysiłku" nad dalszym gospodarczym i kulturalnym rozwojem tzw. Ziem Odzyskanych. Obchody Tysiąclecia Państwa Polskiego miały mobilizować energię i ofiarność społeczeństwa, pogłębiać wiedzę i zainteresowanie przeszłością Polski, a także kształtować i umacniać „patriotyczna jedność społeczeństwa”22.

Przedłożone w uchwale oficjalne deklaracje ze strony polityków nijak się miały do ówczesnych realiów. W rzeczywistości konkurencyjne, państwowe obchody Tysiaclecia miały doprowadzić do neutralizacji działań zwiazanych $z$ rocznica chrztu Polski prowadzonych przez Kościół katolicki. W zwiąku z tym władze państwowe organizowały szereg konkurencyjnych uroczystości i czynów społecznych o charakterze państwowym mających odciagnąć wiernych od uroczystości organizowanych przez episkopat. Do uroczystości państwowych, których przebieg znalazł odzwierciedlenie na łamach „Zwierciadła”, można było zaliczyć: (1) akcję budowy Szkół Tysiąclecia, (2) obchody 550. rocznicy bitwy pod Grunwaldem, (3) obchody Tysiąclecia w Gnieźnie i Poznaniu, (4) Sztafety Tysiąclecia, (5) Defiladę Tysiąclecia.

\section{Szkoły Tysiąclecia}

Pierwsze odniesienia do zaplanowanych przez państwo obchodów Tysiąclecia znalazły się na łamach „Zwierciadła” na początku lat 60. Dotyczyły realizacji jednej z głównych akcji propagandowych zorganizowanych przez państwo, jaką była budowa tysiąca szkół na Tysiąclecie Państwa Polskiego. Na łamach periodyku znajdowały się artykuły odnoszace się do budowy szkół. W tekście zamieszczonym w „Zwierciadle” w 1960 r. między innymi informowano:

Mniej więcej 1000 nowych szkół musi być wybudowane wysiłkiem ogólnospołecznym. Będzie to najpiękniejszy pomnik na Tysiąclecie Państwa Polskiego. ... Akcja społeczna, zainicjowana przez partię nie spotkała się jeszcze $z$ tak szerokim i spontanicznym odzewem jak ta.

\footnotetext{
${ }_{22}$ Bartłomiej Noszczak, „Przygotowania do Milenium chrztu Polski i Tysiąclecia Państwa Polskiego (1956-1965)”, w: idem (red.), Milenium czy Tysiaclecie, (Warszawa : Wydawnictwo Instytutu Pamięci Narodowej, 2006), 27.
} 
Hasło zbudujemy 1000 Szkół na Tysiąclecie Polski trafiło na dobra glebę najlepszych uczuć patriotycznych ${ }^{23}$.

Przywołany artykuł posiadał cechy charakterystyczne dla zapowiedzi prasowej. Wyróżnikiem tej formy gatunkowej było powiadomienie czytelników o rozpoczętej akcji propagandowej. Tekst spełniał dwojaka rolę, zarówno informacji wstępnej, jak i streszczającej. Funkcją dominująca w prezentowanej formie gatunkowej była funkcja anonsowania/ reklamowania rozpoczętej akcji ${ }^{24}$. Dla ideologizacji przekazu prasowego zostały zastosowane słowa sztandarowe, jednoznacznie kojarzace się z obchodami Tysiąclecia, takie jak: „Tysiąc nowych szkół”, „pomnik [szkoły] na Tysiąclecie Państwa Polskiego”, hasło: „Zbudujemy 1000 nowych szkół na 1000 Polski”25. Przywołany typ słów sztandarowych pozwolił wyszczególnić w nich te, które swoją charakterystyczną obecnością w dyskursie politycznym stanowiły element kultury narodowej. Były zarazem słowami sztandarowymi o ograniczonym zasięgu obejmującym wyrazy i wyrażenia ograniczone pod względem politycznym, ideologicznym, organizacyjnym, czasowym. Przytoczone nośne propagandowo hasła i slogany były wprowadzone do dyskursu politycznego na użytek partii rzadzacej w prowadzonej kampanii o charakterze politycznym ${ }^{26}$.

Na łamach „Zwierciadła” informacje o budowie szkół często przybierały również formę sprawozdań, zazwyczaj zwiąanych $z$ oddaniem do użytku budynku szkoły. Dla uatrakcyjnienia treści redakcja umieściła w sprawozdaniu sześć fotografii z przebiegu otwarcia szkoły. Miały one charakter dokumentalny ${ }^{27}$. W artykule zaprezentowano otwarcie szkoły, której budowie patronowało Koło Ligi Kobiet. Pisano:

Inicjatorem i organizatorem budowy szkoły była Wojewódzka Organizacja Ligi Kobiet. Sama zbierała środki finansowe, organizowała świadczenia innych ... Ale organizatorki na jej otwarcie zjawiły się

\footnotetext{
23 „Fakty i komentarze. Tysiąc szkół”, Zwierciadło, t. 22, 1960, 2.

24 Maria Wojtak, Gatunki prasowe, (Lublin : Wydawnictwo Uniwersytetu Marii Curie-Skłodowskiej, 2004), 101-103.

25 „Fakty i komentarze. Tysiąc szkół”, Zwierciadło, t. 15, 1962, 2.

26 Walery Pisarek, Polskie słowa sztandarowe $i$ ich publiczność, (Kraków : Wydawnictwo Universitas, 2002), 10-11.

${ }^{27}$ Według Kazimierza Wolnego-Zmorzyńskiego cechami fotografii dokumentalnej są: „ostrość, dokładność, jasność, zrozumiałość i czytelność zdjęć”, Kazimierz Wolny-Zmorzyński, Jaka informacja? Rzecz o percepcji fotografii dziennikarskiej, (Kraków : Wydawnictwo Uniwersytetu Jagiellońskiego, 2010), 53-54.
} 
$z$ dodatkowym jeszcze wianem. $Z$ prezentami mającymi wyposażyć kuchnię szkolną w naczynia ${ }^{28}$.

W oficjalnie formułowanych przekazach medialnych w odniesieniu do budowy szkół władze PRL dla legitymizacji działań stosowały kilka sprawdzonych chwytów propagandowych. Budowę szkół pomników łączono ze sprawnościa gospodarską włodarzy PRL. Budowane obiekty szkolne przyrównywano do narodowych pomników wzniesionych dla uczczenia Tysiąclecia. Pomniki w postaci szkół miały również mieć wymiar praktyczny. Mianowicie miały spowodować przyspieszenie powojennego zapóźnienia cywilizacyjnego PRL ${ }^{29}$.

Kolejna rocznica o charakterze państwowym wpisującą się w obchody Tysiąclecia państwa była przypadająca na rok 1960 550. rocznica bitwy pod Grunwaldem. Na łamach „Zwierciadła” znalazł się artykuł mający formę relacji ${ }^{30} \mathrm{z}$ przygotowań do zlotu. Redakcja gazety informowała:

Już od kilku dni na polach wsi Grunwald, wysławionych historyczna bitwa, obozują harcerze, członkowie Zwiazku Młodzieży Socjalistycznej i Zwiąku Młodzieży Wiejskiej ... W zlocie weźmie udział 30 tysięcy młodzieży z całego kraju. Między innymi liczne sztafety młodzieżowe, które zakończą tu wędrówkę „Szlakami Jagiełly” ... Dni młodości na Polach Grunwaldzkich będą niewątpliwie jedną z najpiękniejszych i najbardziej pamiętnych uroczystości Tysiąclecia Państwa Polskiego ${ }^{31}$.

Dominującymi słowami sztandarowymi w tekście były leksemy: Grunwald/grunwaldzki (pięć razy), Tysiąclecie Państwa Polskiego (jeden

${ }^{28}$ Zenon Małek, „Liczą się czyny”, Zwierciadło, t. 22, 1960, 2.

29 Krzysztof Wałaszewski, Tysiąc szkół na Tysiaclecie. Szkoły Tysiaclecia-architektura, propaganda, polityka, (Łódź : Dom Wydawniczy Księży Młyn, 2018), 96-100.

30 Cecha przywołanego tekstu był między innymi opis zdarzenia, które jeszcze się nie zakończyło, występowała równowaga równoczesna, czyli narastanie w relacjonowaniu poszczególnych faz zdarzenia. Przywołane słowa sztandarowe miały również za zadanie „ubarwić" przebieg opisywanej sytuacji, vide: Kazimierz Wolny-Zmorzyński, Andrzej Kaliszewski, Wojciech Furman, Gatunki dziennikarskie. Teoria, praktyka, język, (Warszawa : Wydawnictwa Akademickie i Profesjonalne. Grupa Kapitałowa WSiP, 2006), 43.

31 „Młodzież i Grunwald”, Zwierciadło, t. 28, 1960, 2; Małgorzata Gałęzowska, „Świętowanie wybranych rocznic bitwy pod Grunwaldem formą komunikacji państwa i narodu", Kultura i Społeczeństwo, t. 4, 2015, 83-108. Jak wskazuje Anita Młynarczyk-Tomczyk: „Antyniemieckość 550 rocznicy bitwy była spotęgowana doświadczeniami związanymi z przebiegiem II wojny. Widocznymi symptomami negatywnego nastawienia władz państwowych do rewizjonizmu niemieckiego były uobecnione w dyskursie politycznym hasła: nawała krzyżacka, gwałty krzyżackie". Anita Młynarczyk-Tomczyk, Obchody polskiego, 154. 
raz). Komuniści obchody 550. rocznicy bitwy pod Grunwaldem wpisali w zakrojone na szeroka skalę obchody Tysiąclecia Państwa Polskiego. W oficjalnych przekazach propagandowych można było dostrzec kilka tendencji charakterystycznych dla sposobu uczczenia grunwaldzkiej rocznicy. Obchody rocznicy bitwy wpisywały się w komunistyczny proces deprecjacji narodowych symboli oraz w ówczesny model racji stanu polegający na tworzeniu jednoznacznego obrazu wroga w postaci rewizjonistycznych planów NRF. W politycznym dyskursie państwowym w PRL dominowały również odniesienia do rozdziału funkcjonowania Polski przed i po 1945 r. W tworzeniu obrazu RFN przy okazji grunwaldzkiej rocznicy pomocne stawały się nacjonalistyczne stereotypy i uprzedzenia tworzone przez władze PRL względem narodu niemieckiego. Władze państwowe włączenie 550. rocznicy bitwy pod Grunwaldem w katalog rocznic związanych $z$ Tysiącleciem Państwa motywowały tym, że dzieje Polaków związane były z zagrożeniem ze strony zachodnioniemieckiego sasiada. Dlatego upamiętnienie rocznicy grunwaldzkiej uważano za czynnik wielkiej wagi.

\section{Kulminacja sporu w roku 1966}

W roku 1966 na łamach „Zwierciadła” dyskurs polityczny związany z kształtowaniem się sporu o Tysiąclecie Państwa Polskiego oscylował wokół zagadnień związanych ze sporem między władzami państwowymi a episkopatem. Ze strony władz państwowych umieszczano wzmianki informujące o przygotowaniu przez państwo konkurencyjnych wobec kościelnych obchodów. Pisano: „W roku bieżącym, który wieńczy kilkuletni okres obchodów Tysiąclecia przewidziany jest szereg uroczystości o charakterze ogólnokrajowym i bardzo wiele o charakterze lokalnym. Ich punktem kulminacyjnym będzie uroczystość w dniu 22 lipca - w dniu narodzin Polski Ludowej"32. W tekście majacym charakter wzmianki dominującymi słowami sztandarowymi były te związane $z$ państwowościa Polski i obchodami Tysiąclecia. Dominowały takie leksemy, jak: Polska (trzy razy), Polska Ludowa (jeden raz), Tysiaclecie (trzy razy).

Przywołane we fragmencie tekstu działania podejmowane przez władze państwowe miały doprowadzić do jak najszerszej sekularyzacji obchodów proponowanych przez episkopat. Sekularyzacja w założeniu

32 „Podsumowanie dorobku wieków”, Zwierciadło, t. 6, 1966, 2. 
PZPR miała doprowadzić do procesu zanikania religii i religijności w sferze publicznej. Procesy sekularyzacyjne prowadzone przez PZPR na gruncie sporu o Tysiąclecie miały doprowadzić do wyzwalania się człowieka i instytucji społecznych spod wpływów religijnych. Stanowiły również element prowadzonej przez państwo i episkopat swoistej walki o rząd dusz ${ }^{33}$.

Aby odciagnać jak najwięcej osób od uczestnictwa w kościelnej części obchodów, aparat państwowy PRL przygotowywał szereg inicjatyw i zobowiązań inicjowanych oficjalnie „spontanicznie” przez poszczególne grupy społeczne. Dobrym przykładem takiego postępowania były zobowiązania na cześć Tysiąclecia powzięte przez lubelskie działaczki Ligi Kobiet. W zmiance umieszczonej na łamach „Zwierciadła” informowano między innymi o zobowiazzaniu podwyższenia wyglądu estetycznego mieszkań i wiejskich zagród. Ponadto działaczki społeczne podjęły się zorganizowania: „Około 100 różnego rodzaju kursów oraz około 80 odczytów i pogadanek na temat historii Polski" ${ }^{34}$. Podejmowane przez przedstawicieli załóg robotniczych zobowiązania na cześć Tysiąclecia wiazano przede wszystkim $z$ oficjalnymi świętami państwowymi. Dobrym przykładem takiego postępowania było podjęcie przez załogę Zakładów im. Hipolita Cegielskiego w Poznaniu zobowiazań z okazji przypadającego na dzień pierwszego maja Święta Pracy. We wzmiance znajdującej się na łamach „Zwierciadła” dla wzmocnienia przekazu propagandowego stosowano słowa sztandarowe odnoszace się do działalności ruchu robotniczego i klasy robotniczej. Były to między innymi: „Czyn produkcyjny, święto robotnicze, czyn majowy"35. W kontekście przyjętych z okazji Święta Pracy przez robotników zobowiazań godne uczczenie Tysiąclecia wiazano ze specjalnym programem produkcyjnym, ustanowionym programem prac społecznych. Wzmożona aktywność produkcyjna robotników łączono, jak wyrażono w periodyku, $z$ : „poparciem naszych patriotycznych uczuć dla programu partii i władzy ludowej...”36.

Wyraźnym przejawem konfliktu między państwem i Kościołem katolickim uobecnionym na łamach „Zwierciadła” była odmowa zachodnioeuropejskim biskupom wjazdu na centralne uroczystości milenijne

33 Maria Marczewska-Rytko, Religia i polityka w globalizujacym się świecie, (Lublin : Wydawnictwo Uniwersytetu Marii Curie-Skłodowskiej, 2010), 184-185; Millenium polskie. Walka o rzad dusz. red. Cyprian Wilamowski, Warszawa 2002, 185.

34 „Dla uczczenia Tysiąclecia”, Zwierciadło, t. 12, 1966, 2.

35 „Dla uczczenia Tysiąclecia”, Zwierciadło, t. 14, 1966, 2.

36 Ibidem. 
organizowane przez episkopat w sanktuarium na Jasnej Górze. W artykule pod tytułem Komu potrzebna jest nieprawda majacym formę streszczenia listów otwartych przedkładano argumentację dwóch stron sporu politycznego: premiera rządu PRL Józefa Cyrankiewicza i kardynała Wyszyńskiego. Główna oś sporu dotyczyła wydanej przez władze PRL odmowy wjazdu na organizowane przez episkopat uroczystości na Jasnej Górze 56 biskupom z zagranicznych państw. Władze państwowe prześmiewczo deprecjonowały tezy zawarte w liście autorstwa kardynała Wyszyńskiego, twierdząc, że: „Ten list nie jest bynajmniej przepojony "ewangelicznym duchem" soboru" ${ }^{37}$. W streszczeniu odpowiedzi autorstwa J. Cyrankiewicza dokonano wyraźnej identyfikacji wrogów politycznych, jakimi byli biskupi niemieccy. Główny motyw dyskursu propagandowego skupiał się na tezach przygotowanych przez ojców soborowych z Polski. Dla zobrazowania wrogiej działalności Kościoła katolickiego $\mathrm{w}$ środowisku międzynarodowym spożytkowano streszczenie fragmentu listu premiera. Pisano:

Udowadnia on raz jeszcze, że Episkopat podejmując dialog z biskupami niemieckimi na płaszczyźnie przebaczenia win narodu niemieckiego wobec polskiego i prośby o przebaczenie za rzekome winy narodu przekroczył już nie tylko swoje polityczne kompetencje, ale po prostu moralne, bo nikt w Polsce takich pełnomocnictw biskupom nie dał i nikomu u nas nie wpadłoby do głowy prosić Niemców o przebaczenie, a sami biskupi niemieccy też zapewne się tego nie spodziewali, bo wcale o to nie prosili, że będzie im udzielone przebaczenie ${ }^{38}$.

W przytoczonym fragmencie artykułu prasowego komuniści dla zobrazowania w dyskursie politycznym poczynań wroga odnosili się pośrednio do postępowania narodu niemieckiego wobec polskiego w okresie II wojny światowej. Dla wzmocnienia dyskursu politycznego wykorzystali nośniki złej pamięci mające w swej treści utrwalone negatywne konotacje zwiazane $z$ przedmiotem oglądu prezentowanym w dyskursie politycznym i medialnym. W odniesieniu do działań episkopatu komuniści formułowali stwierdzenia o jednoznacznie negatywnej konotacji dla wzmocnienia istniejacych realnych bądź wyimaginowanych zagrożeñ ${ }^{39}$.

\footnotetext{
37 „Komu potrzebna jest nieprawda”, Zwierciadło, t. 12, 1966, 2.

38 Ibidem.

39 Marcin Kula, Nośniki pamięci historycznej, (Warszawa : Wydawnictwo DiG, 2004), 65-70.
} 
W celu dyskredytacji kościelnych obchodów Milenium stosowano technikę oczerniania przeciwnika politycznego zwaną dyskredytacja sztandaru. W słowach sztandarowych zawartych w tekście dyskredytacja objawiała się stosowaniem obraźliwych słów dla zobrazowania nabożeństwa, które nazywano impreza ${ }^{40}$.

Jak wspomniano, główna oś sporu między PZPR a Kościołem oscylowała wokół zagadnienia zwiąanego $z$ treściami zawartymi w powstałym w 1965 r. liście biskupów polskich do biskupów niemieckich. Tytuł artykułu - Pamiętamy nie przebaczamy - był wyraźnym nawiązaniem do słów: „Przebaczamy i prosimy o przebaczenie” - napisanych przez polskich biskupów ${ }^{41}$. Dla umniejszenia doniosłości listu w dyskursie politycznym odwoływano się znów do niedawno zakończonej wojny. Przedstawiano mit Niemiec jako odwiecznego okupanta Polski. Dla zdyskredytowania przedstawicieli duchowieństwa zastosowano zestaw słów sztandarowych o jednoznacznie negatywnej konotacji, stanowiacych poziom zerowy języka polityki. Były to między innymi takie sformułowania, jak: „wsteczny, ciemny, warcholstwo, sobiepaństwo kościelnych wielmożników, organizatorzy spisków, reakcyjna polityka"42.

Kulminacja obchodów Tysiąclecia przypadajacych na dzień 17 kwietnia została zaplanowana w dawnych prastarych grodach stołecznych - Gnieźnie i Poznaniu. Komuniści, chcąc zneutralizować oddziaływanie Kościoła na wiernych, zorganizowali szereg świeckich odpowiedników świąt kościelnych. Przedłożone postawy znalazły wyraziste odzwierciedlenie na łamach „Zwierciadła”. Informacje dotyczace przebiegu uroczystości przybrały formy sprawozdań bądź wzmianek o seryjnej strukturze. Jednak wyróżnikami tematycznymi były zróżnicowane tytuły pełniące funkcję inicjalną, czyli zapowiadająca, co znajdzie się w treści artykułu. W artykule pod tytułem Gwieździsta Sztafeta relacjonowano przebieg biegu. Centralnym elementem opisywanej wzmianki był przedruk apelu uczestników sztafety: „Przynosimy Ci Polsko na

\footnotetext{
40 „Komu potrzebna jest”, 2.

41 Był to celowy zabieg propagandowy bardzo często stosowany w środkach masowego przekazu. Jak wskazuje Mariusz Mazur: „W wielu publikacjach posiłkowano się krótkimi cytatami $z$ orędzia opatrzonymi obfitym komentarzem i interpretacją. Jedną $z$ głównych osi ówczesnych przekazów uczyniono tezę o politycznych intencjach orędzia, które uzasadniano dwojako: powołując się na treść listu i jego wymowę". Mariusz Mazur, Polityczne kampanie w okresie rzadów Władysława Gomułki, (Lublin : Wydawnictwo Uniwersytetu Marii Curie-Skłodowskiej, 2004), 62.

42 „Pamiętamy nie przebaczamy”, Zwierciadło, t. 19, 1966, 2.
} 
Twój jubileusz najpiękniejszy pomnik zbudowany praca całego narodu ... Nowe fabryki, huty i kopalnie, domy mieszkalne, szkoły i internaty. Mają one służyć pomyślności człowieka, jak wszystko co w naszym kraju zbudowaliśmy, budujemy i będziemy budować. Tego dorobku i naszej pokojowej pracy nie pozwolimy nikomu podważyć"43.

W oficjalnym oglądzie stosunków społecznych sztafety miały stać się: wielką manifestacja polityczna poparcia społeczeństwa dla polityki partii i rządu i masową imprezą o charakterze kulturalnym i sportowym. Gwieździste sztafety wyruszyły o jednej godzinie punktualnie z czterech stron Polski, by ich drogi skrzyżowały się w Gnieźnie. Trasa sztafet zaplanowana była tak, aby przebiegały i przejeżdżały przez najważniejsze miasta w województwie ${ }^{44}$. Warto również dodać, że w założeniach partii i rządu sztafeta tysiąclecia miała być świeckim odpowiednikiem złożenia przez katolików ślubów jasnogórskich. Zaś dla zobrazowania przebiegu uroczystości w Poznaniu spożytkowano fragment przemówienia marszałka Polski Mariana Spychalskiego. Polityk w przemówieniu odwoływał się do początków państwowości polskiej w okresie piastowskim. Dokonał również porównania I armii Wojska Polskiego, oddziałów Ludowego Wojska Polskiego oraz oddziałów Armii Czerwonej do oddziałów wojów stanowiących część armii piastowskiej. Klamrą spajająca nakreślone przez Spychalskiego okresy historyczne stały się dokonania Ludowego Wojska Polskiego będącego w ocenie polityka nosicielem wielkiego postępu, jakim w ówczesnych czasach miał być socjalizm ${ }^{45}$.

Dnia 17 kwietnia 1966 r. przypadły kulminacyjne obchody Tysiąclecia Państwa Polskiego zorganizowane przez PZPR w Poznaniu. W uroczystościach uczestniczył I sekretarz KC PZPR Władysław Gomułka. W wygłoszonym przemówieniu dokonał ataku słownego na struktury Kościoła katolickiego. Szczególną uwagę skupił na osobie kardynała Wyszyńskiego. Na łamach „Zwierciadła” dokonano streszczenia przemówienia Gomułki, korzystając $z$ jego obszernych fragmentów. I sekretarz poddał krytyce lansowana przez episkopat na czele $z$ kardynałem Wyszyńskim ideę Polski jako przedmurza chrześcijaństwa ${ }^{46}$. Gomułka ideę

43 „Gwieździsta sztafeta”, Zwierciadło, t. 18, 1966, 2.

${ }_{44}$ Marcin Kula (red.), Przebudować człowieka. Komunistyczne wysiłki zmiany mentalności, (Warszawa : Wydawnictwo Trio, 2001), 318-324.

45 „W Gnieźnie”, Zwierciadło, t. 18, 1966, 2.

46 "Jak wskazuje Andrzej Rajewski: „W trakcie obchodów Milenium oś sporu na płaszczyźnie historycznej między Episkopatem a KC PZPR umiejscowiona była wokół lansowanej 
przedmurza oceniał jako zgubną dla Polski i podważająca filary polityki zagranicznej PRL. I sekretarz zarzucał biskupom „wsteczne cele polityczne i rozgrzeszenie narodu niemieckiego" ${ }^{\prime 7}$. Jednoznacznie negatywnie wypowiadał się o działalności episkopatu pod przewodnictwem kardynała Wyszyńskiego, pisano: „Nie będziemy jednak tolerować sprzecznej $z$ interesami Polski polityki przedmurza jaka uprawia część hierarchii kościelnej na czele $z$ kierownikiem Episkopatu"48.

Gomułka w swej wizji polityki był skłonny tolerować środowiska kościelne. Niewatpliwie podejmowane w roku 1966 działania podyktowane były pragmatyzmem politycznym. Gdyby postapił inaczej, mogłoby to się negatywnie odbić na sytuacji wewnatrz partii. I Sekretarz chciał pozostawić Kościół pod kontrolą państwową ${ }^{49}$.

Ostatnim wydarzeniem przypadającym na rok obchodów Tysiąclecia i ściśle powiazanym $z$ agenda polityczna była defilada wojskowa

przez Wyszyńskiego idei Polski jako przedmurza chrześcijaństwa. Prymas Polskę jako przedmurze chrześcijaństwa pojmował w dwóch wymiarach. Po pierwsze jako istnienie dwóch wzajemnie wykluczających się światów. Świata opartego na wartościach chrześcijańskich oraz świata laickiego. Przedmurze oddzielało jeden obszar kulturowy zbudowany na konkretnych pryncypiach ideowych od drugiego stanowiącego zaprzeczenie świata chrześcijańskiego. Prymas Wyszyński pojmował Polskę jako forpocztę idei przedmurza. Idee chrześcijańskie lansowane przez polski Kościół wedle tego duchownego wkraczały na coraz większy, obcy ideologicznie teren, zmieniając granice świata laickiego i rozszerzając granice świata chrześcijańskiego”. Andrzej Rajewski, „Spór o przeszłość. Historia Polski w narracji Kościoła i państwa w okresie obchodów milenijnych", w: Bartłomiej Noszczak (red.), Pót wieku milenium. Religijne, polityczne i społeczne aspekty obchodów tysiaclecia chrztu Polski (1956-1966/1967), (Warszawa : Wydawnictwo Instytutu Pamięci Narodowej, 2017), 912. Z kolei Gomułka wyraźnie potępił promowaną przez Wyszyńskiego ideę przedmurza. Dla dyskredytacji przeciwnika politycznego używał fraz charakterystycznych dla zerowego poziomu języka polityki. W wygłoszonym przemówieniu mówił między innymi: „Jakże ograniczony i wyzbyty narodowego poczucia państwowości musi być umysł przewodniczącego episkopatu polskiego, który $z$ tych tragedii jakie spotkały Polskę, wyciaga taki tylko wniosek, że naród polski mógł bardzo często być bez króla, i bez wodza i bez zwierzchników, i bez premierów, i bez ministrów, ale naród ten nigdy nie żył bez pasterza. Ten wojujacy $z$ naszym państwem ludowym nieodpowiedzialny pasterz, pasterz, który głosi pretensję, że nie będzie się korzył przed polską racją stanu, stawia swoje urojone pretensje do duchowego zwierzchnictwa nad narodem polskim wyżej niż niepodległość Polski. Jakież to musi być zaślepienie tego kierownika episkopatu polskiego i jego popleczników, lansujących pokraczna, antynarodową idee przedmurza, której treść polityczna w naszych czasach sprowadza się do skłócenia narodu polskiego z narodami sowieckimi, do zerwania sojuszu polsko-sowieckiego. Kierując się wstecznymi celami politycznymi, część hierarchii kościelnej wplotła swoją idee przedmurza do uroczystości kościelnych organizowanych z okazji tysiąclecia wkroczenia chrześcijaństwa na ziemie polskie”, ibidem, 928-929.

47 „W Poznaniu”, Zwierciadło, t. 18, 1966, 2.

48 Ibidem.

49 Anita Prażmowska, Władysław Gomułka, (Warszawa : Wydawnictwo RM, 2017), 224. 
zorganizowana w dniu na 22 lipca 1966 r. Przebieg defilady znalazł odzwierciedlenie w agendzie komunikacyjnej „Zwierciadła” w postaci fotograficznego reportażu prasowego. Zostały wykonane czarno-białe fotografie. Zastosowanie przez redakcję periodyku reportażu prasowego mogło być spowodowane atrakcyjna formą defilady, która odbywała się w dwóch wymiarach - naziemnym i powietrznym. Na ziemi uwage przykuwały barwne stroje rycerzy i żołnierzy polskich z różnych epok historycznych. Zaś w powietrzu samoloty i helikoptery układały się w ciekawe figury (orzel, data 1966) ${ }^{50}$.

\section{Podsumowanie}

Periodyk „Zwierciadło” był elementem medialnego systemu propagandowego ukształtowanego po II wojnie światowej, gdy na tereny tzw. Polski Lubelskiej przybyli „instruktorzy” tworzacy zręby nowego, komunistycznego systemu państwowego. Tygodnik miał być odpowiedzia na zapotrzebowanie na nowy tytuł prasowy dedykowany dla kobiet $z$ inteligenckich kręgów społeczeństwa. „Zwierciadło” posiadało bogata, profilowana ofertę treściowa dla swoich odbiorców. Spór o Tysiąclecie Państwa Polskiego znalazł wyraziste odzwierciedlenie na łamach magazynu. Składał się na niego szereg rocznic i świąt o charakterze państwowym. Do głównych tego typu akcji należy zaliczyć zainicjowana przez PZPR akcję budowy 1000 szkół na Tysiąclecie Państwa. Popularna formą uczczenia Tysiąclecia były podejmowane zobowiazania robotnicze. W obchody Tysiaclecia komuniści wpisywali również katalog rocznic państwowych (bitwa pod Grunwaldem). Główna oś sporu między PZPR a Kościołem oscylowała wokół treści listu biskupów polskich do niemieckich i lansowanej przez kardynała Wyszyńskiego polityki Przedmurza. Kierownictwo partii przygotowało wiele konkurencyjnych świeckich uroczystości Tysiąclecia często nawiązujących luźno do ich kościelnych odpowiedników.

50 „W Poznaniu”, 2. 


\section{Bibliografia}

\section{Akty prawne}

Uchwała Rady Państwa z dnia 18 II 1958 r. w sprawie przygotowań do Obchodów Tysiąclecia Państwa Polskiego, „Monitor Polski” 1958, nr 12, poz. 78.

Uchwała Sejmu Polskiej Rzeczypospolitej Ludowej z dnia 25 II 1958 r. w sprawie obchodów Tysiąclecia Państwa Polskiego, „Monitor Polski” 1958, nr 16, poz. 58.

\section{Źródla}

„Dla uczczenia Tysiąclecia”, Zwierciadło, t. 12, 1966, 2.

„Dla uczczenia Tysiaclecia”, Zwierciadło, t. 14, 1966, 2.

„Fakty i komentarze. Tysiąc szkół”, Zwierciadło, t. 22, 1960, 2.

„Fakty i komentarze. Tysiąc szkół”, Zwierciadło, t. 15, 1962, 2.

„Gwieździsta sztafeta”, Zwierciadło, t. 18, 1966, 2.

„Komu potrzebna jest nieprawda”, Zwierciadło, t. 12, 1966, 2.

LM, ŻM, „Ojciec i syn”, Zwierciadło, t. 46, 1966, 8.

Małek, Zenon. „Licza się czyny”, Zwierciadło, t. 22, 1960, 2.

„Młodzież i Grunwald”, Zwierciadło, t. 28, 1960, 2.

„Pamiętamy nie przebaczamy”, Zwierciadło, t. 19, 1966, 2.

„Podsumowanie dorobku wieków”, Zwierciadło, t. 6, 1966, 2.

„W Gnieźnie”, Zwierciadło, t. 18, 1966, 2.

„W Poznaniu”, Zwierciadło, t. 18, 1966, 2.

\section{Opracowania}

Adamski, Franciszek. „Konflikty małżeńskie i ich źródła na łamach »Kobiety i Życia"”, Zeszyty Prasoznawcze, t. 1, 1978, 27-35.

Adamski, Franciszek. Modele małżeństwa i rodziny a kultura masowa, (Warszawa : PWN, 1970).

Bajka, Zbigniew. Czytelnictwo prasy w Polsce w 1986 roku, (Kraków : RSW-Prasa-Ksiażka-Ruch, 1987).

Ćwik, Urszula. „Zagadnienia praw kobiet na łamach "Kobiety i Życia" (19701989)", Czasopismo Naukowe Instytutu Studiów Kobiecych, t. 1, 2016, 66-83. 
Dajnowicz, Małgorzata. „Posłanki Ligi Kobiet Polskich i wybory parlamentarne 1989 roku (prezentacja w świetle „Zwierciadła”)”, w: Małgorzata Dajnowicz, Adam Miodowski (red.), Polityka i politycy w prasie XX i XXI wieku. Polityka w prasie kobiecej, (Białystok : Wydawnictwo Uniwersytetu w Białymstoku, 2019), 205-215.

Dajnowicz, Małgorzata. „Walka o pokój" w wypowiedziach propagandowych publikowanych na łamach "Naszej Pracy" - biuletynie Ligi Kobiet (19471953)", w: Ewa Maj, Wojciech Sokół, Anna Szwed-Walczak, Łukasz Jędrzejski (red.), Bezpieczeństwo Europy - bezpieczeństwo Polski, t. 5, (Lublin : Wydawnictwo Uniwersytetu Marii Curie-Skłodowskiej, 2017), 409-421.

Dajnowicz, Małgorzata. "Zwierciadło" - platforma polityczna Ligi Kobiet w okresie PRL (1957-1961, 1982-1989)", Rocznik Historii Prasy Polskiej, t. 20, 2017, 67-90.

Drozdowska, Agnieszka. „Liga Kobiet w województwie białostockim - stan badań i postulaty badawcze", Czasopismo Naukowe Instytutu Studiów Kobiecych, t. 2(5), 2018, 112-127.

Gałęzowska, Małgorzata. „Świętowanie wybranych rocznic bitwy pod Grunwaldem formą komunikacji państwa i narodu”, Kultura i Społeczeństwo, t. 4, 2015, 83-108.

Kalbarczyk, Ryszard. „Kto czyta pismo kobiece?”, Nasze problemy, t. 3, 1979, $35-40$.

Kantyka, Zbigniew. „Politologia (I)”, w: Wojciech Sokół, Marek Żmigrodzki (red.), Encyklopedia politologii, t. 1, Pojęcia, teorie i metody, (Warszawa : Wydawnictwo Wolters Kluwer, 2016).

Konarska, Krystyna. Łoś, Maria. Łaskot, Małgorzata. „Czasopisma kobiece czy rodzinne?”, Więź, t. 9, 1965, 55-73.

Kula, Marcin. Nośniki pamięci historycznej, (Warszawa : Wydawnictwo DiG, 2004).

Kula, Marcin (red.), Przebudować człowieka. Komunistyczne wysiłki zmiany mentalności (Warszawa : Wydawnictwo Trio, 2001).

Lisowska-Magdziarz, Małgorzata. Analiza tekstu w dyskursie medialnym, (Kraków : Wydawnictwo Uniwersytetu Jagiellońskiego, 2006).

Maliszewska, Anna. „Wzory wychowawcze w prasie kobiecej (szkoła i rodzina jako instytucje wychowawcze)", Zeszyty Prasoznawcze, t. 4, 1975, 15-25. 
Marcinkiewicz-Kaczmarczyk, Anna. „Rola kobiety w Polsce Ludowej w świetle treści propagandowych rozpowszechnianych przez Lige Kobiet w latach 1946-1956", Dzieje Najnowsze, R. L, z. 2, 2018, 149-179.

Marczewska-Rytko, Maria. Religia i polityka w globalizujacym się świecie, (Lublin : Wydawnictwo Uniwersytetu Marii Curie-Skłodowskiej, 2010).

Markiewicz, Henryk. Romanowski, Andrzej. Skrzydlate słowa, (Warszawa : Państowy Instytut Wydawniczy, 1990).

Mazur, Mariusz. Polityczne kampanie w okresie rzadów Władysława Gomułki, (Lublin : Wydawnictwo Uniwersytetu Marii Curie-Skłodowskiej, 2004).

Młynarczyk-Tomczyk, Anita. Obchody „polskiego Tysiaclecia” (19571966/67), (Kielce : Wydawnictwo Uniwersytetu Jana Kochanowskiego, 2019).

Noszczak, Bartłomiej. Polityka wobec Kościoła rzymskokatolickiego w Polsce w okresie internowania prymasa Stefana Wyszyńskiego 1953-1956, (Warszawa : Wydawnictwo Instytutu Pamięci Narodowej, 2008).

Noszczak, Bartłomiej. „Przygotowania do Milenium chrztu Polski i Tysiąclecia państwa polskiego (1956-1965)”, w: Bartłomiej Noszczak (red.), Milenium czy Tysiaclecie, (Warszawa : Wydawnictwo Instytutu Pamięci Narodowej, 2006), 10-39.

Pisarek, Walery. O mediach i języku, (Kraków : Wydawnictwo Universitas, 2007).

Pisarek, Walery. Polskie słowa sztandarowe i ich publiczność, Polskie słowa sztandarowe $i$ ich publiczność, (Kraków : Wydawnictwo Universitas, 2002).

Pisarek, Walery. Wstęp do nauki o komunikowaniu, (Warszawa : Wydawnictwa Akademickie i Profesjonalne, 2008).

Pokorna-Ignatowicz, Katarzyna. „Od leninowskiej koncepcji prasy do wolnych mediów. Koncepcja "nowego ładu informacyjnego" w "Porozumieniach Okragłego Stołu", w: Katarzyna Pokorna-Ignatowicz (red.), Polski system medialny 1989-2011, (Kraków : Oficyna Wydawnicza AFM, 2013), 13-34.

Pokorna-Ignatowicz, Katarzyna. Robotnicza Spółdzielnia Wydawnicza „Prasa-Ksiażka-Ruch" w polskim systemie medialnym, (Warszawa : Oficyna Wydawnicza AFM, 2016). 
Prażmowska, Anita. Władysław Gomułka, (Warszawa: Wydawnictwo RM, 2017).

Sokół, Zofia. Prasa kobieca $w$ Polsce $w$ latach 1945-1995, (Rzeszów : Wydawnictwo Wyższej Szkoły Pedagogicznej, 1998), 146-147.

Sokół, Zofia. „Transformacja czasopism kobiecych w Polsce (1989-1997)”, Rocznik Historii Prasy Polskiej, t. 1, 1998, 60-75.

Sokół, Zofia. „Wzór osobowy kobiety i model rodziny propagowany na łamach prasy kobiecej w latach 1945-1990”, w: Weronika Chańska, Danuta Ulicka (red.), Polskie oblicza feminizmu, (Warszawa : Wydawnictwo Uniwersytetu Warszawskiego, 2000), 70-99.

Szczepańska, Sabina. „Kobieta - zwierzę polityczne?”, w: Małgorzata Radkiewicz (red.), Gender - kultura-społeczeństwo, (Kraków : Wydawnictwo Rabit, 2002), 91-100.

Truszczykowski, Marek. Kościół Rzymskokatolicki w Polsce na tle polityki władz partyjno-państwowych PRL w latach 1956-1980, (Szulborze Wielkie : BW, 2011).

Wałaszewski, Krzysztof. Tysiąc szkół na Tysiąclecie. Szkoły Tysiąclecia-architektura, propaganda, polityka, (Łódź : Dom Wydawniczy Księży Młyn, 2018).

Wojtak, Maria. Gatunki prasowe, (Lublin : Wydawnictwo Uniwersytetu Marii Curie-Skłodowskiej, 2004).

Wolny-Zmorzyński, Kazimierz. Jaka informacja? Rzecz o percepcji fotografii dziennikarskiej, (Kraków : Wydawnictwo Uniwersytetu Jagiellońskiego, 2010).

Wolny-Zmorzyński, Kazimierz. Kaliszewski, Andrzej. Furman, Wojciech. Gatunki dziennikarskie. Teoria, praktyka, język, (Warszawa : Wydawnictwa Akademickie i Profesjonalne. Grupa Kapitałowa WSiP, 2006).

Zajko-Czochańska, Justyna. „Kobiety i wybory na łamach „Przyjaciółki” w latach 1956-1976”, Czasopismo Naukowe Instytutu Studiów Kobiecych, t. 1(6), 2019, 138-150.

\section{Źródła internetowe}

Stowarzyszenie Instytut Studiów Kobiecych, [dostęp: 3.01.2020]. Dostępny w World Wide Web: http://www.isk.bialystok.pl/. 